Digitalizacja archiwalnych numerów czasopisma naukowego Analecta Cracoviensia 1-24 (1969-1992)

i ich publikacja w otwartym dostępie - zadanie finansowane w ramach umowy 672/P-DUN/2017 ze środków

Ministra Nauki i Szkolnictwa Wyższego przeznaczonych na działalność upowszechniającą naukę

JAN SAMEK

\title{
O RUTENIKACH W ZBIORACH KRAKOWSKICH
}

Problem importów i tych historycznych, i tych dokonanych w XIX stuleciu w sztuce Krakowa nie doczekał się dotąd szerszego opracowania. Pozostaje więc droga mozolnego budowania syntezy poprzez publikacje cenniejszych obiektów oraz wskazywanie na ważniejsze problemy. Do takich cennych zabytków należy nieznana, odnaleziona w czasie prac do Katalogu zabytków miasta Krakowa, późnobarokowa puszka na komunikanty w niewielkim skarbcu kościoła św. Katarzyny na Kazimierzu w Krakowie. Jej artystyczne walory, autor i jego oeuvre oraz inne rutenika w Krakowie i Polsce będą tematem niniejszego artykułu.

\section{NIEZNANE DZIEŁO PIOTRA AFINOGIENOWA}

Przedmiot naszych badań - puszka na komunikanty w skarbcu kościoła Sw. Katarzyny na Kazimierzu w Krakowie wykonana została ze srebra i pozłocona. Wysokość jej z pokrywą wynosi $405 \mathrm{~mm}$. Przy wykonywaniu naczynia posłużono się techniką trybowania, lania, rycia i cyzelowania. Podstawa puszki jest okrąła, o pokaźnej średnicy, znacznie dłuższej od średnicy czary. Dekoracja pokrywająca czarę to głównie plastyczne, dobrze wykształcone ornamenty rokokowe oraz cztery usytuowane poziomo duże owalne plakietki z przedstawieniami figuralnymi, o których będzie jeszcze mowa. Trzon naczynia jest dość wątły, wzbogacony pierścieniami o wielkim, gładkim, gruszkowym nodusie. Czara o wywiniętym brzegu, w jednej piątej od góry gładka, posiada podobną dekorację jak stopa. Zdobi ją dekoracja motywami rokokowymi oraz tak jak na stopie - cztery duże plakietki owalne, tym razem w układzie pionowym. Gładką pokrywę wieńczy zamknięta korona o dwóch krzyżujących się pałąkach, wzbogacona dość grubo wykonaną dekoracją roślinną, imitacjami kaboszonów i kameryzacją; całość wieńczy krzyżyk. Mimo widocznej chęci dopasowania do naczynia, pokrywa czyni wrażenie dodatku. Według wszelkiego prawdopodobieństwa mamy tu do czynienia z przeróbką. Najpewniej kielich mszalny przerobiono na puszkę na komunikanty, co nie wymagało poza wykonaniem pokrywy prawie żadnych zmian. Wróćmy jednak do plakietek. Na sto- 
pie wyobrażono na nich Chrystusa w Ogrójcu, Biczowanie i Upadek pod krzyżem (czwarte pole zdobi nowsza plakietka, przedstawiająca Matkę Boską Częstochowską). Cztery plakietki na czarze wypełniają wyobrażenia Chrystusa, Krzyża, Matki Boskiej i św. Jana Chrzciciela. Interesująca jest technika, jaką posłużył się złotnik. Postacie, teren, architektura, obłoki i przedmioty wydobyte zostały techniką rytu. Tło pokrywa natomiast wydatne, może nawet zbyt agresywne puncowanie, które uczytelnia postacie i przedmioty. Przedstawienia na plakietkach nie są finezyjnie wykonane. Autor nie zwracal zbytniej uwagi na poprawne proporcje figury ludzkiej, a nawet zarys rąk i twarzy. Posiadał natomiast umiejętność nadania pewnej ekspresji gestom i wyrazom twarzy. W sumie przedstawienia na plakietkach jasno się tłumaczą (wreszcie mają krótkie napisy), o co zapewne chodziło wykonawcy.

Jako dzieło sztuki złotniczej, naczynie posiada znaczną wartość artystyczną, Składają się nań wyważone proporcje, oczywiście inne od stosowanych w Krakowie, bogata dekoracja i oryginalnie potraktowane plakietki. Fundację objaśnia napis cyrylicą, umieszczony w kartuszach na stopie. Brzmi on: POSTROJENO W MOSKWIE BYTNOSTNIU [PÓŁKOWNIKA] KNIAZIA SIERGIJA NIKITICZA TRUBIECKOWA / W LIETO W ROŻDIESTWA CHRISTOWA / 1761 MASKW[A]. Na górnej części czary ponad koszyczkiem czytamy: JADI MOJU PŁOT I PIJAJ MOJU KROW, BO MNIE PREBYWAJE JAZI WNIEM. Unowocześnione tłumaczenie tych napisów brzmi; ze stopy: „Wykonano w Moskwie za bytności pułkownika księcia Siergieja Nikitycza Trubeckiego w roku od narodzenia Chrystusa 1761 Moskwa"; z czary: „Kto spożywa moje ciało i pije moją krew, będzie we mnie przebywać a ja w nim".

Na naczyniu widnieją też punce: miasta Moskwy - święty Jerzy walczący ze smokiem i data 1766; imienne - ПA i B-A (obie w prostokątach) oraz AOP (w sercu) i E K (w prostokącie) ${ }^{1}$. Punca A odnosi się niewątpliwie do złotnika Piotra Afinogienowa, którym zajmiemy się nieco bliżej. Cecha B-A dotyczy nie znanego $\mathrm{z}$ nazwiska mistrza probierczego, czynnego w latach $1760-$ 1794. Punca $z$ literami w sercu należy natomiast do mistrza od jakości (Aldermana), także nie znanego z nazwiska, który działał w latach 1775 - 1804 (cecha w formie serca używana była w latach 1775 - 1802, później w miejsce tego znaku występuje dwucyfrowa próba srebra). Wreszcie cecha $\mathrm{z}$ literami E K w prostokącie znana jest jako punca nie zidentyfikowanego mistrza (z roku 1765).

Powyższe wyjaśnienia wskazują, że naczynie jest dziełem znanego złotnika moskiewskiego Piotra Afinogienowa, który urodził się w roku 1726, czynny zaś był w drugiej połowie stulecia. Zachowało się nieco dzieł tego znanego mi-

\footnotetext{
${ }^{1}$ W rozwiązaniu punc oparto się na pracy: M. M. Post nik ow a - Łosie wa, Russkoje juvielirnoje isskustwo. Jewo centry i mastiera XVI-XIX, Moskwa 1974. Autor wyraża podziękowanie Pani mgr Stanisławie Odrzywolskiej za pomoc w tym zakresie.
} 
strza. W Państwowym Muzeum Historycznym w Moskwie dotrwały sukienki na ikony, krzyż, kadzielnica oraz kielich (nr inw. 60088 nr OK 5665). Również w zbiorach Orużejnoj Pałaty na Kremlu oglądać można kielich roboty tego złotnika $^{2}$. Szczególowe badania przeprowadzone przez autora rozprawy na miejscu w Moskwie pozwoliły na stwierdzenie, że wszystkie prace Afinogienowa są bardzo do siebie podobne. Kielich w Państwowym Muzeum Historycznym pochodzi z 1761 roku i posiada, jak w Krakowie, bogatą dekorację rokokową i plakietki. Przedstawiono na nich, jak na naczyniu w skarbcu kościoła Sw. Katarzyny, wyobrażenia chrystologiczne. Stopę dekorują w czterech polach Arma Christi, natomiast koszyczek czary wyobrażenia Chrystusa z chorągwią, Matki Boskiej i Krzyża. Równie bliski krakowskiemu zabytkowi jest kielich przechowywany na Kremlu.

Tak oto dzięki badaniom przeprowadzonym w Krakowie wzbogacona została wiedza o warsztacie Afinogienowa. Należał on do złotników moskiewskich późnego baroku i rokoka, prowadzących warsztaty czynne w znacznej mierze w duchu stylów zachodnioeuropejskich.

\section{PROBLEM RUTENIKÓW W KRAKOWSKIM ZŁOTNICTWIE I W POLSKIM RZEMIOŚLE ARTYSTYCZNYM}

Problem ruteników w sztuce polskiej jest zagadnieniem bardzo rzadkim. Należy zatem ograniczyć go tutaj do rzemiosła artystycznego, a nawet do złotnictwa. Trudno jednak nie przypomnieć na tym miejscu ważniejszych wzmianek i cenniejszych zabytków z terenu Krakowa, ze zbiorów kościelnych i muzealnych. Już z 1. połowy XV wieku znani są czynni w Krakowie złotnicy ruskiego pochodzenia. Jeden z nich - Jerzy Ruski (Jürge Rewsse), wzmiankowany w latach 1415 - 1445 - mieszkał przy ulicy Grodzkiej, a w roku 1415 wybrany został na starszego cechu wraz z Hanusem Firynkiem ${ }^{3}$. Prawdopodobnie jego synem był złotnik Jerzy, występujący w latach 1466 i 1477, zmarły w Krakowie przed 1478 rokiem. Drugim mistrzem ruskiego pochodzenia był złotnik Jan Rusin (Rewse), który pełnił funkcję starszego cechu wraz z Maciejem Ole ${ }^{4}$. W odniesieniu do wybitnego dzieła złotnictwa krakowskiego tego okresu (relikwiarz św. Stanisława z czasu po roku 1422) wysunięto nawet hipotezę o domniemanym wpływie sztuki bizantyjsko-ruskiej na złotnictwo krakowskie.

Mniejwięcej z tego czasu, zapewne z początku XV wieku pochodzi najcenniejsze krakowskie ruthenicum: skrzyneczka „lekarska” w skarbcu kościoła Mariackiego w Krakowie. Skrzyneczka ta, uważana za wyrób południoworus-

\footnotetext{
${ }^{2}$ Oba zabytki miałem okazję zbadać w czasie pobytu w Moskwie na stypendium Instytutu Sztuki PAN. w r. 1979.

${ }^{3}$ B. Pr z y b y s ze w s ki, Ztoty Dom Królestwa. Studium z dziejów krakowskiego cechu ztotniczego od czasu jego powstania (ok. 1370) do potowy wieku XV, Warszawa 1968, s. 49 - 50.

${ }^{4}$ Tamże, s. 51.
} 
ki, wykonana z miedzi i złocona, jest dziełem Samuela Kowala oraz Elizeusza prezbitera i Lewonteja pisarza ${ }^{5}$. Zabytek zdobią liczne ryty; na ściankach fryz z przedstawieniem cudów świętych Kosmy i Damiana: uzdrowienie chorego na pląsawicę, uleczenie wielbłąda opętanego przez diabła, uzdrowienie ślepego i chromego (w dwóch wersjach), uśmierzenie bólu zębów, wypędzenie żmii, uzdrowienie kobiety w pół zgiętej, uzdrowienie bliżej nieokreślonego chorego, wskrzeszenie syna wdowy, uleczenie chorego od wielu cierpień, wypędzenie diabła z opętanego; sceny z życia tych świętych: narodzenie, spór o przyjęcie nagrody po uzdrowieniu Palladii, śmierć; na wieku popiersia śś. „cudotwórców": Flora, Ławra, Jerzego, Samsona, Awiwa, Spirydiona, Mikołaja, Grzegorza, Borysa, Gleba, Elizeusza, i śś. „nie nagrodzonych”: Kosmy i Damiana (trzykrotnie), bliżej nieokreślonego świętego, Pantelejmona, Kirosa, Jana, Samsona, Falielieja, oraz dwie sceny: uzdrowienie ślepych i chromych przy grobie śś. Kosmy i Damiana, uleczenie chorego na ból głowy. Nad poszczególnymi przedstawieniami oraz dookoła wieka biegną liczne napisy cyrylicą. Niestety to wybitne i unikatowe dzieło sztuki nie doczekało się dotąd odpowiedniego opracowania.

Z XVI i XVII stulecia trudno wskazać rutenika w krakowskich skarbcach kościelnych, można natomiast znaleźć je w zbiorach muzealnych. Posłużmy się przykładami. W Muzeum Narodowym w Krakowie, zbiory Czartoryskich, przechowywany jest srebrny, częściowo złocony kubek z 1595 roku o niewiadomym pochodzeniu (nr inw. MNK-XIII-32) ${ }^{6}$. Jak świadczy napis na naczyniu, jest to dzieło nie znanego bliżej Wasyla, syna Gliga. Na skromną dekorację kubka, nieopracowanego dotąd monograficznie, składają się motywy stylizowanych smoków, wstęgi, rozety oraz twarz ludzka. Analogie do kubka z 1595 roku wskazano w zbiornikach Orużejnoj Pałaty w Moskwie ${ }^{7}$.

Także w zbiorach Czartoryskich znajduje się czara, tzw. kowsz, datowana na 2. połowę XVII wieku ${ }^{8}$. Tutaj można nieco więcej powiedzieć o proweniencji. Naczynie znajdowało się bowiem już w świątyni Sybilli w Puławach i według tradycji, umocnionej napisem, miało być własnością Łukasza Opalińskiego. Wykute ze srebra, częściowo złocone, miało kształt typowej dla rosyjskich wyrobów płytkiej czary o bogatej dekoracji kwiatowo-roślinnej z motywami goździków, peonii, tulipanów, żonkili i słoneczników z bogatą rytą dekoracją

${ }^{5}$ M. i S. Cerchowie, F. Kopera, Pomniki Krakowa, t. 3, Kraków-Warszawa 1904, nlb.; M. L. D a u e 1, Iconographie des saints médecins Cosme et Damian, Lille 1958; Katalog zabytków sztuki w Polsce, t. IV: Kraków, cz. 2: Kościoły i klasztory Śródmieścia 1, pod redakcją A. B oc h $\mathrm{n}$ a k a i J. S a m k a, Warszawa 1970, s. 38 (il. 816, 818); J. S a m e k, Importy w polskim rzemiośle artystycznym (na przyktadzie ztotnictwa i jubilerstwa), [w:] O rzemiosle artystycznym $w$ Polsce. Materiały Sesji naukowej zorganizowanej przez oddzial poznański Stowarzyszenia Historyków Sztuki i Muzeum Narodowe w Poznaniu przy wspólpracy Przedsiębiorstwa „Desa” w 1973 r., Warszawa 1976,; por. także Z. Pi e ch, Corpus inscriptionum Poloniae t. VIII: Woj. krakowskie, zeszyt 2: Bazylika Mariacka, Kraków 1987.

6 J. B u jań s k a, Stare srebra, Kraków 1972, s. 46 poz. 10.

${ }^{7}$ Tamże.

${ }^{8}$ Tamże, poz. 19. 
na zewnątrznej ściance. Podobne czary spotkać można w licznych moskiewskich zbiorach ${ }^{9}$.

Lukę, jaką stanowi w krakowskich rutenikach wiek XVIII, wypełnia omówiona w niniejszym artykule puszka moskiewskiej roboty.

Natomiast z początku wieku XX, z roku 1910, pochodzi bardzo interesujący zabytek: pastorał wykonany ze srebra przez nadwornego jubilera carskiego Karola Fabergé, przywieziony do Polski w r. 1918 przez arcybiskupa Simona ${ }^{10}$. Posiada on formy i dekorację eklektyczną przy użyciu kameryzacji, która nawiązuje w pewnym stopniu do ruskich a nawet bizantyjskich wyrobów.

Prawdopodobnie $\mathrm{z}$ tego samego warsztatu wyszły przechowywane w kościele Mariackim trzy skromnie dekorowane naczynia na oleje święte z końca XIX wieku. Warto jeszcze wspomnieć, że w kościele pijarów pw. Przemienienia Pańskiego znajduje się patena z ruskim napisem z około r. 1900.

Jakież byłyby wnioski z tego małego przeglądu? Rutenika w dziedzinie złotnictwa należą w Krakowie do rzadkości. Tylko nieliczne z nich są importami historycznymi. Zresztą pojęcie to należy elastycznie traktować, albowiem zachodzą tu różne możliwości. Jak wiadomo zabytki znajdujące się w zbiorach klasztornych dość często wędrowały i nadal wędrują jako swoiste przerzuty w ramach poszczególnych domów klasztornych. Poza tym nie należy zapominać o fakcie, że wędrówki zabytków miały szczególnie miejsce po pierwszej i drugiej wojnie światowej. To zjawisko właściwie należy traktować niemal na równi z importami historycznymi.

Sumując stwierdzić należy, co następuje:

1. W polskim rzemiośle artystycznym, w szczególności w interesującym nas złotnictwie istnieją wyraźne i ważne grupy importów. Dla przypomnienia: są to wyroby węgierskie w czasach późnego gotyku i renesansu; norymberskie i włoskie w czasach renesansu i manieryzmu; wyroby augsburskie, nadal włoskie, francuskie i pochodzące z Bliskiego Wschodu w epoce baroku; wreszcie wiedeńskie (zjawisko to jest też uchwytne w XVIII i XIX stuleciu).

2. Importy ruskie należą do zdecydowanie słabiej zaznaczających się, a przede wszystkim nie opracowanych. Spróbujmy zatem spojrzeć na to zjawisko w skali ogólnopolskiej.

\section{RUTENIKA W SKALI POLSKIEJ}

O rutenikach w skali polskiej w odniesieniu do rzemiosła artystycznego nie pisano dotąd w ogóle. Niewątpliwie da się je wymienić w dziedzinie między innymi wyrobów złotniczych, broni, ceramiki i tkanin. Aby nie być gołosłow-

\footnotetext{
${ }^{9}$ Miałem okazję przekonać się o tym w trakcie badań nad złotnictwem przeprowadzonych w czasie pobytu w Moskwie.

${ }_{10}$ J. S a m e k, Skarbiec kościoła Mariackiego w Krakowie (mps).
} 
nym, pragniemy zasygnalizować zagadnienie tzw. składów - pektorały odnajdywane na różnych terenach (Krosno, Przemyśl, Gniezno) ${ }^{11}$. Osobne zagadnienie stanowią szyszaki znajdujące się w pobliskich zbiorach do niedawna uważane za wyroby polskie, obecnie uznane za ruskie ${ }^{12}$.

W dziedzinie wyrobów ceramicznych pragniemy zasygnalizować interesujące związki, łączące przeniesione z Wiśniowca na Wawel piece z XVIII wieku $\mathrm{z}$ ozdobnymi kaflami o cechach barokowych $\mathrm{z}$ terenu Rosji ${ }^{13}$. Tkaniny rosyjskie z XIX w. możemy spotkać w licznych szatach liturgicznych. Natomiast szczególne zjawisko nastąpiło w okresie po rozbiorach, kiedy na terenie zaboru rosyjskiego w wielu miejscowościach, między innymi w Warszawie, Kielcach i Częstochowie powstawały cerkwie wymagające odpowiedniego wyposażenia. Były więc nie tylko naczynia liturgiczne, lecz także liczne sukienki na obrazy. Wyroby te w czasie ostatniej wojny często zmieniały miejsce przechowywania, ale w dużym stopniu się zachowały. Znakomite zbiory ruskich sreber, w znacznej części sygnowanych, zachowały się do dziś między innymi w zbiorach cerkwi w Kielcach ${ }^{14}$ i Częstochowie ${ }^{15}$. Te grupy ruteników, które znalazły się na terenie Polski w wyniku specyficznej sytuacji historycznej, nie występują oczywiście w takim stopniu, jak w „Królestwie”, na terenie zaboru pruskiego i austriackiego. W każdym razie, kończąc rzecz o wybranych ruthenikach w zbiorach krakowskich, trzeba powiedzieć, że są one $\mathrm{z}$ tego punktu widzenia ciekawą grupą obok zasobów wszystkich dawnych i czynnych obecnie cerkwi w Polsce. Albowiem mimo postępu badań ciągle nie mamy jasnego obrazu importów w dziedzinie rzemiosła artystycznego, a ściślej mówiąc złotnictwa w sztuce polskiej. Byłoby niezwykle interesujące wybranie najcenniejszych wyrobów z tej dziedziny i opublikowanie ich pod wspólnym tytułem: importy w polskim złotnictwie.

\section{RUTHENICA IN DEN KRAKAUER SAMMLUNGEN}

\section{Zusammenfassung}

Während die aufs polnische Gebiet von außen eingegangenen Kunstwerke immer wieder erforscht werden, haben die Ruthenica - russische Kunstgegenstände kein näheres Interesse der Forscher bis jetzt erweckt. Es hat sich jedoch erwiesen, daß es viele Ruthenica auch in Krakau gibt,

11 Sztuka polska przedromańska i romańska do schytku XIII w., Warszawa 1971, s. 723 (il. 1207), s. $751-752$ (il. 1204), s. 691 (il. 1203).

12 J. S a me k, Polskie rzemiosto artystyczne. Sredniowiecze (w druku).

${ }^{13}$ Zwrócił na to uwagę autor niniejszej pracy; por. też: M. Dą b row sk a, Kafle, i piece kaflowe w Polsce do końca XVIII wieku, Wroclaw-Warszawa..., 1987, s. 40 (przypis 21).

${ }^{14}$ Dokumentację srebrnych wyrobów w cerkwi w Kielcach opracowała Pani mgr Maria Kłosińska na zlecenie Biura Dokumentacji Zabytków w Kielcach.

${ }_{15}$ Srebra w cerkwi w Częstochowie opracowali na zlecenie Biura Dokumentacji Zabytków w Częstochowie mgr Aleksander Broda i Jerzy Żmudziński. 
die in den Kirchensammlungen aufbewahrt werden. Durch seinen hohen künstlerischen Wert zeichnet sich unter den Kunstschätzen das Ziborium (ursprünglich ein Messkelch) vom Jahre 1761 aus, gegenwärtig in der Schatzkammer der St. Katharina Kirche aufbewahrt. Dieses spätbarocke Werk mit 7 Medaillons verziert (am Knauf und Fuß) hat eine Inschrift, die besagt, daß es 1761 in Moskau angefertigt worden ist. Die Goldschmiedezeichen weisen darauf hin, daß der Ausführende ein bekannter Moskauer Goldschmied Piotr Afinogienow geb. 1726 war. Mehrere Werke dieses Meisters sind erhalten geblieben, darunter die dem Krakauer Werk ähnlichen Kelche im Historischen Staatsmuseum in Moskau und in den Sammlungen der Rust- und Schatzkammer (Orużejna Pałata) in Kreml.

Es ist zu erwähnen, daß russische Goldschmiede schon in der ersten Hälfte des 15. Jahrhunderts in Krakau tätig waren, bestimmt im Auftrag des Königs Władysław Jagiełło herbeigeholt, oder aber wenigstens mit seinem litauisch-russischen Hof irgendwie verbunden. Ein prächtiges Werk der russischen Goldschmiedekunst ist ein Kästchen mit reicher Gravierung, wahrscheinlich aus dem Anfang des 15. Jahrhunderts, in der Schatzkammer der Marienkirche verwahrt.

Die erhaltenen Ruthenica aus dem 16. und 17. Jh. werden im Nationalmuseum in Krakau untergebracht. Es sind: ein Becher aus dem Jahre 1595 und eine Schale aus der 2. Hälfte des 17. Jahrhunderts. Es gibt auch russische Kunstgegenstände aus dem 19. und 20. Jh., u.a. in der Marienkirche und Piaristenkirche in Krakau. Die zahlreichen erhalten gebliebenen Werke der russischen Herkunft zeugen von der Bedeutung der Ruthenica in dem polnischen Kunstgewerbe. 